\title{
STRATEGIC MANAGEMENT OF HuMAN RESOURCES FOR GLOBAL COMPETITIVE ADVANTAGE
}

\author{
Abagail McWilliams \\ University of Illinois at Chicago \\ Chicago, IL \\ David D. Van Fleet \\ Arizona State University West \\ Phoenix, AZ \\ Patrick M. Wright \\ Cornell University \\ Ithaca, NY
}

\begin{abstract}
This article extends the literature on the role of human resources in global competitiveness by focusing on the ability of transnational firms to create a sustainable competitive advantage through the strategic management of their work force. We focus on the ability of managers to strategically draw from multiple human resource labor pools, creating a competitive advantage for transnational firms vis-a-vis domestic and multinational firms. A model, which extends the resource-based view of the firm, is developed.
\end{abstract}

\section{Strategic Management of Human Resources for Global Competitive Advantage}

Recent conceptual and empirical work has focused on how firms go about developing and maintaining a competitive advantage ${ }^{1}$ (Barney, 1991; Lawler, 1992; Lawler, 1996; Peteraf, 1993; Wernerfelt, 1984; Wright, McMahan \& McWilliams, 1994). This focus on competitive advantage requires additional consideration in light of the increasingly global nature of competition, as evidenced by surveys of U.S. business. Twenty-six percent of U.S. managers surveyed indicated that their companies had recently expanded internationally. The percentage increased to 45 for firms with 1,000 or more employees (Kanter, 1991). The rise in U.S. exports is additional evidence of the growing importance of global competition. Exports currently account for 11 percent of the Gross Domestic Product of the U.S., and have been growing at a rate of 12 percent a year since 1987 (Norton, 1993).

One of the keys to successful competition in the global market is the effective deployment of human resources to achieve a competitive advantage (Schuler, Dowling \& De Cieri, 1993). Much of the research on the role of human resources 
in global competitiveness has focused on management (Adler \& Bartholomew, 1992a; Adler \& Bartholomew, 1992b; Bass \& Burger, 1979; Doz \& Prahalad, 1988; Ratiu, 1983). The effectiveness of management techniques across cultures and the difficulties of adjustment both in the work place and in the social environment have been cxtensively examined (Black \& Porter, 1991; Lee \& Larwood, 1983; Mendenhall \& Oddou, 1985; Tung, 1981). The role of the remainder of the firm's work force in achieving competitive advantage in the global marketplace has received much less attention. The purpose of this paper is to explore how human resources, defined as the entire pool of employees, constitute a potential source of sustainable competitive advantage for transnational firms.

In order to achieve this aim, we first distinguish transnational firms from multinational and domestic firms. We then use the resource-based view of the firm to examine how human resources can form a source of sustainable competitive advantage for domestic firms (Peteraf, 1993; Barney, 1991; Wernerfelt, 1984). Building on this discussion, we explore the additional ways in which the human resources of a transnational firm can constitute a source of sustained competitive advantage. Finally, we discuss the managerial implications of our analysis.

\section{Levels of Global Competition}

Firms differ in the extent to which they participate in global competition. Adler (1991) categorizes firms as domestic, international, multinational, and transnational, depending on the level to which they participate in global competition. ${ }^{2}$ Understanding the differences across these categories is helpful to understanding the role of human resources in global competition and the need for human resource management (HRM) systems commensurate with the rigors of global competition.

Domestic. Most companies begin by operating within a domestic marketplace. This entails having all of the firm's facilities, employees, and customers within the boundaries of one country. While employees may differ to some extent in terms of their regional or ethnic cultural orientations, the pool of employees is relatively homogeneous. Thus, it is important to note that firms functioning at the domestic level of participation face an environment very similar with regard to culture, human capital, political/legal systems, and economic systems, although some variation might be observed across states and geographical areas.

International. As domestic markets become saturated, firms often seek other markets for their products. These firms tend to regard their international markets as simple extensions of their domestic operations (Bartlett \& Ghoshal, 1998). This usually requires entering international markets, initially by exporting products, but ultimately by building production facilities in other countries. An international firm 
that is essentially a collection of relatively independent operating subsidiaries is also termed a multidomestic firm (Griffin \& Pustay, 1996). The decision to participate in international competition raises a host of human resource issues. One consideration is whether a particular location provides an environment where human resources can be successfully acquired and managed.

Multinational. Whereas international firms build one or a few facilities in another country, firms become multinational when they build facilities in a number of different countries, attempting to capitalize on lower production and distribution costs associated with different locations. Multinational firms are sometimes referred to as global (Bartlett \& Ghoshal, 1998) because they tend to view the world as a single market and strive to provide standardized goods or services to meet the needs of all markets simultaneously (Griffin \& Pustay, 1996). The lower production costs are gained by shifting production from highercost locations to the lower-cost locations. The HRM problems faced by multinational companies are similar to those faced by international companies, only magnified. Instead of having to consider only one or two countries' cultural, human capital, legal, and economic systems, the multinational company must address these differences for a large number of countries.

Transnational. Many researchers now propose a fourth level of integration: transnational organizations. Transnational organizations compete on state-ofthe-art, top-quality products and services and do so with the lowest costs possible. They try to combine the advantages of global-scale efficiencies (like a multinational firm) with those of local responsiveness (like an international firm) (Griffin \& Pustay, 1996). Whereas multinational companies focusing on economies of scale attempt to develop identical products distributed worldwide, transnational companies increasingly focus on economies of scope and emphasize flexibility and mass customization of products to meet the needs of particular clients. Multinational firms are usually driven to locate facilities in a particular country as a means of reaching that country's market or as a means to achieving lower production costs, and then must "deal with" the differences across countries. Transnational firms, on the other hand, choose to locate facilities based on the ability to effectively, efficiently, and flexibly produce a product or service, and to create synergies through the cultural differences. Production and research and development that benefit from uniform standards and scale economies tend to be centralized, whereas marketing and HRM tend to be decentralized to take advantage of local cultural differences (Griffin \& Pustay, 1996; Hannon, Huang \& Jaw, 1995).

This creates the need for HRM systems that encourage flexible production, thus creating a host of HRM issues. Transnational firms proactively consider the cultures, human capital, political/legal and economic systems to determine locations where production facilities can be located to provide a competitive advantage. These firms have multiple headquarters spread across the globe, resulting in less hierarchically structured organizations that emphasize decen- 
tralized decision-making. This results in the need for human resource systems that recruit, develop, retain, and utilize managers and executives who are not only competent transnationally but also are competent in decision-making in flattened, non-hierarchical organizations. In a transnational firm, the HRM issue is no longer where to find the work force but "'what strategic advantages do our labor resources give us?' and 'what operations should we be planning in order to apply them most effectively?"' (Mead, 1998, 358).

Adler and Bartholomew (1992a) point out that a transnational HR system should be characterized by three attributes, which they describe as transnational scope, transnational representation, and transnational process. The first attribute, transnational scope, refers to the fact that HR decisions must achieve a global, rather than a national or regional, scope. This creates the necessity to ensure that decisions reflect a balancing of the needs for uniformity (to ensure fair treatment of all employees) and flexibility (to meet the needs of employees in different countries). The second attribute, transnational representation, reflects the multinational composition of a firm's managers. To achieve transnational scope, each country should be represented in the managerial ranks of the firm. Having transnational representation is also a prerequisite if the firm is to achieve the third attribute. The third attribute, transnational process, refers to the extent to which the firm's planning and decision-making processes include representatives and ideas from a variety of cultures. It is this attribute that allows for the diversity of viewpoints and knowledge, associated with different cultures, that increases the quality of decision-making. This is a process of negotiation whereby subsidiaries propose strategic initiatives and the centralized unit "co-ordinates, criticises, approves and adds its own funds" (Trompenaars, 1993, 174).

In conclusion, the entry into international markets creates a host of HRM issues that must be addressed if the firm is to gain competitive advantage. Moreover, these issues become more complex as the firm increases its level of international involvement. However, these issues also create an immense potential for a firm's human resources to provide a source of competitive advantage. In the next section, we use the resource-based view of the firm to examine the potential for firms to use human resources as a source of sustained competitive advantage, particularly in an international context. This discussion will provide the foundation for exploring this role in the special case of the transnational firm.

\section{The Role of Human Resources in Competitiveness}

Recent research in the strategic management area has focused on the role of heterogeneous firm resources in achieving and sustaining competitive advantage (Peteraf, 1993; Barney, 1991; Wernerfelt, 1984). This emerging paradigm is called the resource-based view of the firm and has become increasingly popular for explaining why firms differ in performance (Wernerfelt, 1995). According to this view, the internal resources of the firm are responsible for 
competitive advantage and are the source of sustained competitive advantage (Amit \& Schoemaker, 1993).

While it has been demonstrated that resources in and of themselves contribute positive returns to organizations (Miller \& Shamsie, 1996; Pennings, Lee \& van Witteloostuijn, 1998), it is the interaction of resources and strategy that seem to form the basis of sustainable competitive advantage (Schoenecker \& Cooper, 1998). Barney (1991) developed a model that demonstrates that, for a resource to be the source of sustained competitive advantage, it must create value $(V)$ for the firm; it must be rare (R); it must be inimitable (I); and it must be nonsubstitutable (S).

Applying Barney's VRIS framework of sustained competitive advantage, Wright, McMahan, and McWilliams (1994) demonstrate that human resources (defined as the total pool of human capital under the control of the firm) have the highest probability (among all resources) of being the source of sustained competitive advantage for the firm. This is because human resources are more likely than other resources to be inimitable and non-substitutable, as well as being valuable and rare (Wright, McMahan \& McWilliams, 1994). We use this argument to support our first point, that a firm should focus on its entire pool of human resources, as outlined below.

\section{Human Resources as a Pool of Human Capital}

We distinguish between human resources as individuals (or an elite group of individuals such as top management teams) and human resources as the total pool of human capital. Barney (1991) emphasized that human capital resources refer to the characteristics of both managers and workers in the firm, and speculated that the managerial team might constitute a source of competitive advantage. Wright, McMahan, and McWilliams (1994), however, argue that the larger pool of human capital that constitutes the entire organization is more likely to be a source of sustained competitive advantage. Therefore, consistent with Wright, McMahan, and McWilliams, we focus on the larger pool of human capital.

\section{Human Resources as Valuable}

According to the resource-based view, a resource must first be valuable in order to provide a source of sustainable competitive advantage. Firm Specific Human Capital Theory provides an explanation of the conditions under which human capital can create value for the firm (Hashimoto, 1981). According to this theory, when the demand for labor is heterogeneous (that is, when the jobs of firms differ and these jobs require different skills) and the supply of labor is heterogeneous (that is, individuals differ in both the types and levels of their skills), then human capital can create value for the firm. Steffy and Maurer (1988) provide evidence that, in fact, the demand for and supply of labor are heterogeneous across most industries. 
The demand for labor is more heterogeneous across countries than it is within countries due to differences in capital availability, labor practices, and social and cultural norms relating to work. Labor supply is also more heterogeneous across countries than within countries, due to differences in such things as nutrition, sanitation, health care, and training and educational opportunities. Therefore, there is more opportunity for creating value through human resources as competition becomes more global.

Empirical evidence also supports the idea that the demand for and supply of labor are heterogeneous, at least with regards to skill levels of individuals. For example, virtually all of the work with regard to personnel selection (Guion, 1991), training (Goldstein, 1991), and utility analysis (Boudreau, 1991) has demonstrated that more highly skilled individuals outperform lower skilled individuals, and that these performance differences provide value to firms (Hunter \& Hunter, 1984). Lawler (1996) argues that human resources must have power, information, knowledge, and rewards (PIKRs) to be a source of competitive advantage. Clearly, more skilled individuals are more likely to possess these.

\section{Human Resources as Rare}

A resource must also be rare if it is to be a source of sustained competitive advantage. Because human skills are normally distributed in the population (Jenson, 1980), human resources with high skill levels are, by definition, rare. That is, only a relatively small proportion of individuals in any human resource pool will have high skill levels. To the extent that jobs require skills, which allow for variance in individual contributions and human resources vary in quality, job-relevant skills will be rare. Thus, to the extent that jobs require skills that allow for variance in individual contributions, firms with high average skill levels relative to their competitors possess a rare resource. In addition, firms that, because of their international operations, can draw from more than one labor pool have a greater potential for developing this valuable and rare resource. Therefore, firms that, because of their international operations, can draw from more than one labor pool have a greater potential for developing a humanresource-based sustainable competitive advantage than do domestic firms that can draw from only one labor pool. Transnational organizations by virtue of transnational representation and a transnational process are particularly able to draw upon the rare components of their multiple labor pools, and are, thus, more likely to develop sustainable competitive advantages.

\section{Human Resources as Inimitable}

Unless a resource is difficult to imitate, it cannot be the source of a sustainable competitive advantage. Barney (1991) argues that resources will be more difficult to imitate in the presence of causal ambiguity and social complexity. Causal ambiguity exists when the link between a firm's resources and its competitive 
advantage is imperfectly understood (Reed \& DeFillippi, 1990). In the case of human resources, if competing firms cannot identify the human resources that are responsible for the competitive advantage, or the way in which human resources create the competitive advantage, they cannot imitate the advantage. Human resources often lead to causal ambiguity because of team production. With team production, it is difficult to isolate and identify the particular human resources (individuals) that produce the superior performance of the team (Alchian \& Demsetz, 1972).

Social complexity may arise from transaction-specific relationships, and the competitive advantage these relationships create may be due to transactionspecific human capital, i.e., human capital, such as knowledge, that is of value only in the focal transaction (Becker, 1964). It is possible that relationships between key personnel such as sales representatives and buying agents will develop over time and become part of a network that includes a larger group of personnel such as design and marketing staff, production and distribution workers, and management, as well as final consumers. A very complex social situation may result and this may constitute a competitive advantage for the firm. Although the relationship may be too complex to dissect, it is reasonable to speculate that the value of the focal relationship may be due to transactionspecific human capital, that is, the knowledge and trust that are developed over time by the focal personnel and which have value only in the focal relationship. Human resources and social complexity are intrinsically linked because social complexity, by definition, must result from human interactions.

For firms involved in global markets, causal ambiguity and social complexity may be particularly important barriers to imitation. Differences in customs and norms of behavior may make it impossible for outsiders to understand, and therefore imitate, a competitive advantage based on human resources. Additionally, religious, cultural, and political alliances may create strong webs of social complexity that make imitation of an advantage virtually impossible. On the other hand, differences in religion, culture, and politics may prevent the creation of relationships that could, otherwise, lead to a competitive advantage. Thus, causal ambiguity and social complexity strongly influence the inimitability of human resources, especially in a global marketplace. Transnational organizations by emphasizing transnational representation and by developing transnational processes are better able to exploit these local phenomena in achieving sustainable competitive advantage.

\section{Human Resources as Nonsubstitutable}

A resource must also pass the test of having no good substitutes if it is to be the source of a sustainable competitive advantage. This raises the question of whether or not other resources, such as technology, have the potential for offsetting any competitive advantages obtained from human resources. Good substitutes are unlikely, because human resources are one of the few firm resources 
which have the potential to be transferable across a variety of technologies, products, and markets, and to not become obsolete.

Many human capital resources are quite generalizable. For example, general human capital resources such as learning capability are transferable across a wide variety of technologies, products, and markets (Harrigan \& Dalmia, 1991). In addition, if a firm has obtained individuals with high levels of learning capability, then constant training in state-of-the-art technological skills ensures that the resource does not become obsolete.

Therefore, we argue that, while it might be possible to substitute other resources in the short term, it is highly unlikely that such substitution would eliminate the advantage of the human resources for long. This stems from the fact that, to the extent that the resource offsetting the advantage of human resources is not, in and of itself, rare, inimitable, and non-substitutable, then it will be imitated and human resources will once again constitute a competitive advantage. For example, consider a firm, Firm A, which has high ability individuals who are highly committed to the organization, thus constituting a source of competitive advantage. What happens if a competitor, Firm B, develops a new technology, which provides productivity increases greater than the productivity differences stemming from Firm A's work force? If the technology is imitable, then Firm A will also install the new technology and Firm A's human resources will once again constitute a competitive advantage.

It is worth noting here that technology is becoming increasingly internationalized. Transnational firms are likely to have $R \& D$ facilities in more than one country, and technology advances by one company in one country are likely to increase the rate of technological advance and productivity of other firms in other countries, because of the globalization of competition (Mansfield, 1984). Technology may be easier to imitate (or substitute around) as competition becomes more global for a number of reasons. First, the number of companies with comparable R\&D resources increases as an industry becomes global. Second, the amount of knowledge available to build on increases as the number of firms increases. And, third, property rights to intellectual capital become increasingly hard to protect. This argues that, as competition becomes increasingly global, technology is increasingly imitable, which, in turn, argues for the increasing importance of human resources as a source of sustainable competitive advantage.

\section{Human Resources as a Source of Advantage in Transnational Firms}

In order to examine how human resources can provide a competitive advantage to transnational firms, we must first explore how this advantage takes place domestically. Two aspects of human resources work together to create a competitive advantage for the firm. First, there are the knowledges, skills, and abilities (KSAs) inherent in the individuals who make up the organization 
(Flamholtz \& Lacey, 1981; McKelvey, 1983), or the power, information, knowledge, and rewards (PIKRs) that can be developed for these individuals (Lawler, 1996). Second, there are the employee behaviors that are necessary for translating those into productivity for the firm. Wright and Snell (1991) present an open system model of the HRM System, which explicitly notes the interrelationships between employee KSAs/PIKRs and employee behaviors. According to this model, KSAs/PIKRs are necessary, but not sufficient, for employee behavior to be in line with a firm's strategic goals.

Therefore, we explicitly recognize that, while employee behavior is the most direct way in which strategies are implemented, employees must have the competencies (KSAs/PIKRs) necessary to exhibit the appropriate behaviors. This can be seen in the model represented in Figure 1. As depicted in Figure 1, firm strategies and culture both separately and through interaction determine appropriate HR practices, which affect (through selection and retention) both the human capital pool (including KSAs/PIKRs) and exhibited behaviors. The human capital pool and behaviors, together, may create sustainable competitive advantage, and their effects may be enhanced by causal ambiguity and social complexity as explained in the previous discussion.

Figure 1

A Model of Human Resources as a Source of Sustained Competitive Advantage

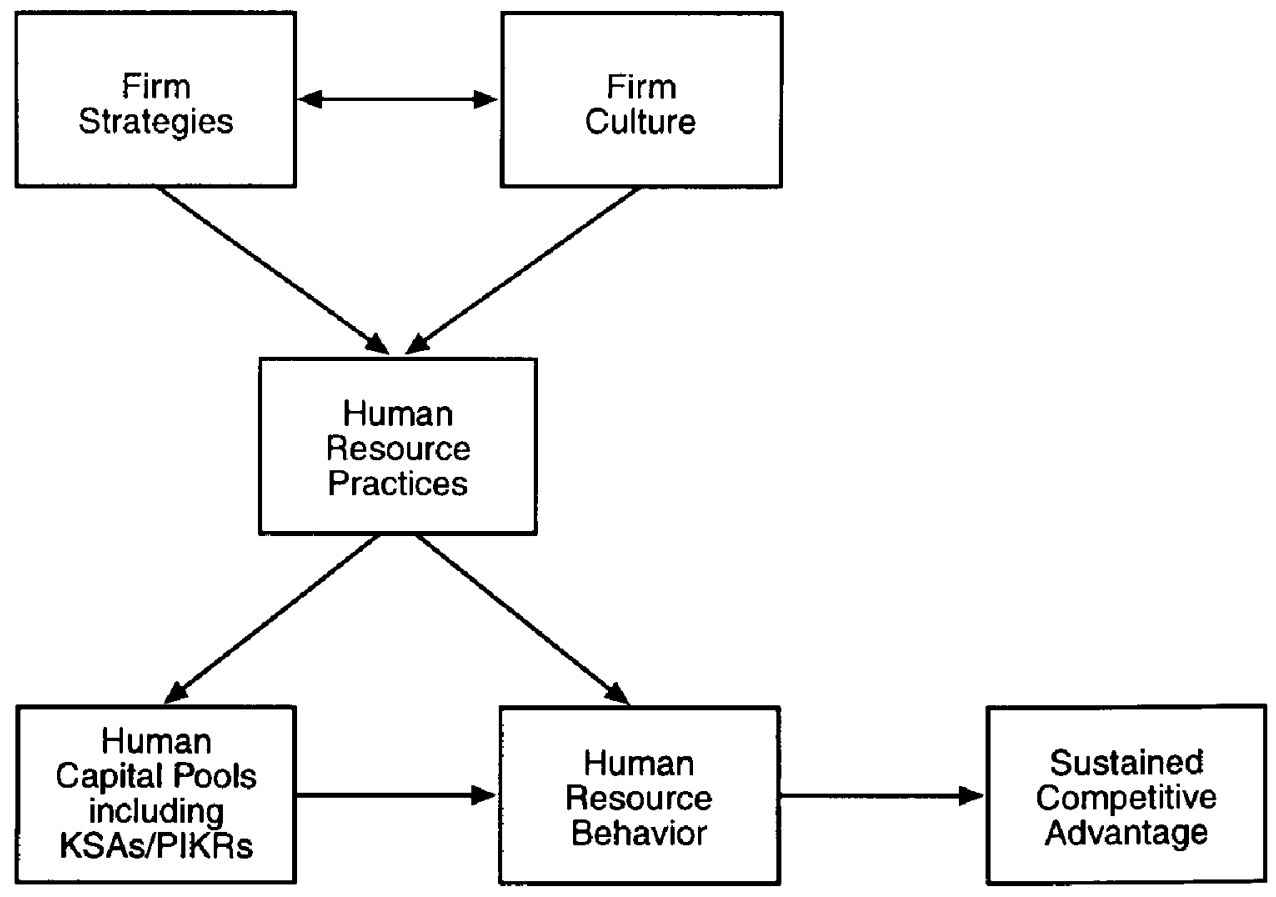

Source: adapted from Wright, McMahan, and McWilliams, 1994 
The sustainable competilive advantage depicted in Figure 1 stems from two mechanisms. First, higher level human capital enables a firm to have productivity advantages relative to its competitors. For example, given the strong linear relationship between human capital skills such as cognitive ability and job performance (Hunter \& Hunter, 1984), one could assume that the firm with superior human capital resources in terms of cognitive ability should, ceteris paribus, achieve higher productivity levels. Second, the firm with superior human capital should have advantages in flexibility and adaptability. Snow and Snell (1992) argue that the continuing globalization of markets will result in more rapid environmental changes, which will require flexibility and adaptability from the work force. As international barriers are dropped at an increasing rate, firms are faced with increasingly dynamic and competitive environments, which necessitate quick responses. These responses must be evidenced throughout the entire work force, and may require quickly learning and applying new skills, implementing new technologies, and/or reorganizing the way work gets done (Snow \& Snell, 1992). A firm with higher levels of human capital relative to its competitors should have an advantage in the ability of its work force to be flexible and adaptable to new market demands and new technologies (Harrigan \& Dalmia, 1991). Therefore, a firm with superior human resources has the potential for sustainable competitive advantage.

Given this model of how human resources can provide a source of sustainable competitive advantage to a firm competing in a given market, it is now possible to broaden this discussion to the transnational firm. We argue that human resources can provide additional sources of sustainable competitive advantage for transnational firms in two ways: (1) by capitalizing on multiple labor pools including KSAs/PIKRs, and (2) by exploiting the cultural synergies inherent in a diverse work force.

\section{Capitalizing on Multiple Labor Pools}

Transnational firms have the potential to develop superior human capital pools, because they can draw from many different labor pools. That is, being transnational adds a choice variable for the firm, as depicted in Figure 2. There are two significant differences between Figure 1 and Figure 2. First, Figure 2 includes a box that represents the human resource decisions of top-level managers in transnational firms. Second. Figure 2 shows that transnational firms have multiple human capital pools from which to choose the most appropriate workers.

The human resource decisions of transnational managers include both the choice of labor pools from which to draw workers and the appropriate practices for managing diverse labor pools. Remembering that labor pools differ across countries, the transnational manager has the opportunity to not only draw from superior labor pools, but to draw from many of them and to match the attributes of different labor pools to the different needs of the firm (Bartlett \& Ghoshal, 
1998). For example, MicroSoft uses programmers in India, because of the highly educated, high quality labor pool available there.

Figure 2

A Model of Transnational Human Resource Management for Sustained Competitive Advantage

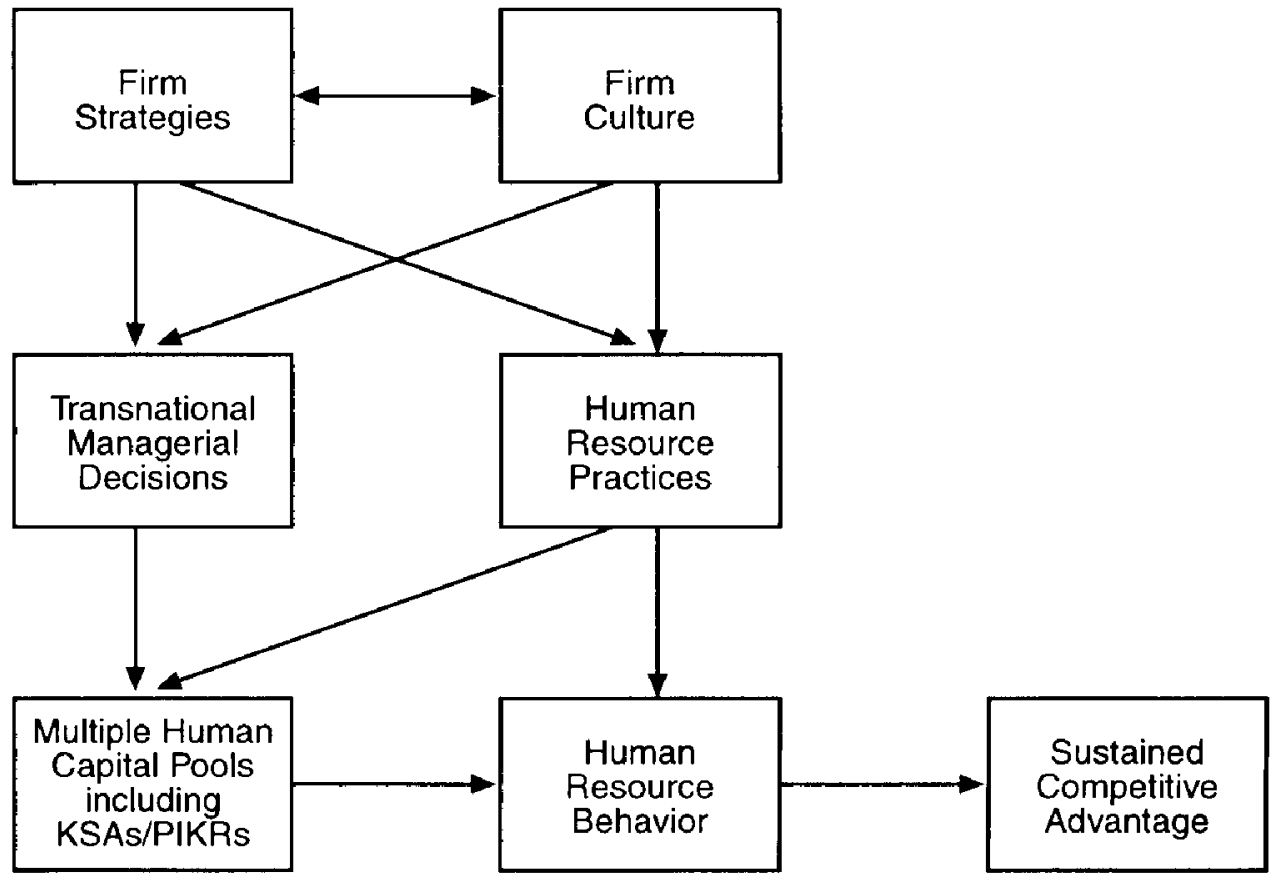

The heterogeneity of demand for, and supply of, labor creates the potential for a sustainable competitive advantage, because the transnational firm has an additional opportunity that is not open to other types of firms. The transnational manager can choose labor pools that offer superior talent for different links in the firm's value chain or for different firm/market demands. For example, some labor pools may have workers who, on average, have higher cognitive ability or have had greater access to education and training. (The quality of workers may also differ because of the available infrastructure, labor practices, and social and cultural norms relating to work.) The transnational firm would be able to draw from the highest quality labor pools for those functions that require high cognitive ability and education and training. This creates a potential advantage over 1) domestic firms, which can choose from only one labor pool; 2) multidomestic firms in which each international division chooses from its local labor pool; and 3) multinational firms, which emphasize economies of scale and are, therefore, strongly influenced by least-cost considerations. Because of increasing global 
competitiveness, transnational firms must pay attention as much to quality, state-of-the-art design, and cultural appropriateness as to cost minimization (Adler \& Ghadar, 1990; Adler \& Bartholomew, 1992a). The additional requirements of quality, state-of-the-art design, and cultural appropriateness increase the pay-off for superior human resources.

Returning to our argument that many human capital resources are quite generalizable, choosing from the highest quality labor pools creates an additional advantage for the transnational firm. As stated earlier, general human capital resources such as learning capability are transferable across a wide variety of technologies, products, and markets (Harrigan \& Dalmia, 1991). This may create an important competitive advantage, because many transnational firms have R\&D facilities in more than one country and transfer technology (especially product technology) extensively across facilities and countries (Mansfield, 1984). The transnational firm would, therefore, be able to benefit from the ability of its superior labor force to use technologies developed in all of the firm's facilities, regardless of the country of origin (Hitt, Dacin, Levitas, Arregl $\&$ Borza, 2000). Firms with superior human resources could expect their workers to adapt more quickly and more effectively to new technologies. Therefore, those firms whose human capital resources are superior would be able to maximize the benefit of technology transfers.

The rapid development of a transnational human capital pool may be a partial explanation for the increasing use of strategic alliances as an entry mechanism into international markets (Osborn \& Hagedoorri, 1997). However, international strategic alliances have frequently not worked well (Madhok \& Tallman, 1998). One reason for this has been lack of sufficient attention to selecting the correct partner (Hitt, Tyler, Hardee \& Park, 1995). Hitt, Dacin, Levitas, Arregle and Borza (2000) have demonstrated that partner selection is not only critical but also varies across emerging and developed market contexts.

\section{Exploiting Diversity and Cultural Synergy}

The use of multiple labor pools provides the potential for firms to increase the quality of global business decision-making. A firm, which employs culturally diverse labor pools, has a distinct pool from which to develop managers. This creates the potential for higher quality, flexible decisions. We recognize two ways in which having managers from different cultural backgrounds may increase decision quality. First, managers from specific countries bring to the process tacit knowledge of aspects of that country's political, cultural, legal, and economic situation. This knowledge might mitigate against faulty decision-making that has resulted in a plethora of business blunders (Ricks, 1993). Second, in addition to the tacit knowledge of specific customs and requirements, having managers from a variety of cultures increases the diversity of viewpoints in terms of values, problem definition, and problem solving. Given the existing empirical evidence that such het- 
erogeneity of viewpoints increases decision quality (Watson, Kumar \& Michaelson, 1993), diversity among decision-makers should ensure that higher quality decisions are made.

That diversity also necessitates flexibility. Managers in transnational organizations must be capable of applying their skills throughout the organization, not just in one location. A geocentric policy of managerial development and staffing is required to assure that transnationals are able to assure this flexibility among their managers (Welch, 1994).

However, the diversity inherent in multiple labor pools also presents a challenge that may result in an additional source of sustainable competitive advantage. Managing multiple labor pools adds an additional area of responsibility for transnational managers. To maximize the potential benefit of drawing from the highest quality labor pools, the transnational manager must be able to elicit the appropriate behaviors. Drawing from more than one labor pool means that the diversity of workers to be managed will be greater. As the work force becomes more diverse, aligning workers' behavior with the firm's goals becomes more difficult.

Adler and Bartholomew (1992a) point out that many transnational firms are ill equipped to manage transnational labor forces. They do not have a multitude of executives "who can think, lead, and act from a global perspective" (Kim, 1999, 228). They are ill equipped because their top managers' lack 1) international experience, 2) experience or training in cultural diversity, and 3) a global perspective about the worldwide business environment. Because of these shortcomings, many firms are not establishing truly transnational human resource systems. Therefore, the firms that can do so will surely have a competitive advantage, at least in the short run. In the long run, the sustainability of this competitive advantage will depend on the superiority of the labor force assembled and the HR practices developed for managing it (Wright, McMahan \& McWilliams, 1994).

\section{Stickiness - A Potential Problem}

All of the above potential for utilizing multiple human capital pools as a source of sustainable competitive advantage relies on the capabilities within those pools being readily transferable. Transferring capabilities is not easy, and, while studies of such transfers between organizations exist, little research has been done on internal transfers such as those required here (Grant, 1991; Prahalad $\&$ Hamel, 1990). The difficulty of transferring capabilities within an organization is referred to as internal stickiness (Szulanski, 1996).

Four sets of characteristics influence the degree of stickiness. They are characteristics of the knowledge itself, of the source, of the receiver, and of the circumstances within which the transfer is to take place. While anecdotal evidence, speculation, and conventional wisdom seem to suggest that the 
major causes of internal stickiness are individual motivational factors, such as perceived threats to advocates of the old paradigm (Zupan, 1991), research suggests otherwise (Szulanski, 1996). The major causes of internal stickiness are "the lack of absorptive capacity of the recipient, causal ambiguity, and an arduous relationship between the source and the recipient" (Szulanski, 1996, 36).

Absorptive capacity refers to the extent of knowledge the receiver has prior to the transfer. The more knowledge the receiver has, particularly knowledge relevant to the situation at hand, the easier or less sticky the transfer will be. Causal ambiguity is related to tacitness (Simonin, 1999) and refers to the receiver's understanding about cause-effect relationships involved in the capabilities to be transferred. Again, the greater the receiver's understanding, the less sticky or easier the transfer will be. Finally, the better the quality of the relationship between sender and receiver, the more likely the receiver will accept and internalize information involved in the transfer. This would suggest that if startup costs are shared so as to minimize free-rider problems (Zupan, 1991), potential stickiness problems would be reduced.

The differences in education levels, type of education, culture, language, and the like that are faced by transnational managers exacerbate these potential sources of stickiness. Instead of trying to use incentive programs to overcome internal stickiness, firms should devote their time and resources to foster closer relationships among individuals and units within those firms and to develop the learning capacities of individuals (Si \& Bruton, 1999; Szulanski, 1996). As relationships and communication improve and learning develops, internal stickiness will become less of a problem and the potential for utilizing multiple human capitad pools as a source of sustainable competitive advantage will increase. Transnational firms are in excellent positions to focus their efforts on developing the learning capacities of their pools of human capital. This argues for an additional benefit derived from superior labor pools - the ability to overcome stickiness.

One way to foster such closer relationships is to recognize that the type of knowledge to be shared is a strong moderating factor. It is much easier to share knowledge of the same type than mixtures. One method that has been suggested for easing the stickiness problem, then, is to organize subunits in a multiunit organization in terms of the type of knowledge involved - simple versus complex or by assuring that acquisitions all involve only one type of knowledge (Hansen, 1999). Another is the use of strategic communities such as the transition alliance teams used by Xerox to facilitate necessary communication (Storck \& Hill, 2000). This is further supported by research by Bresman, Birkinshaw, and Nobel (1999) who show that knowledge transfer is facilitated by visits and meetings that improve the overall pattern of communication within organizations. 


\section{Summary and Practice Implications}

The purpose of this paper is to extend the existing literature on the role of human resources in global competitiveness by examining the contribution of a firm's human resources in the attainment of sustainable competitive advantage in today's global marketplace. This examination gives rise to several implications for managers in the global marketplace.

First, consistent with the resource-based view of the firm developed by Wernerfelt (1984), Barney (1991) and others, our analysis points out that human resources, defined as the entire pool of human capital under the control of the firm, are the most likely source of a sustainable competitive advantage, because human resources are more likely than other resources to be inimitable and nonsubstitutable, as well as valuable and rare.

Second, for transnational firms, causal ambiguity and social complexity may be particularly important barriers to imitation. Causal ambiguity becomes an important barrier to imitation because differences in customs and norms of behavior may make it impossible for outsiders to understand, and therefore imitate, a competitive advantage based on human resources. Similarly, social complexity becomes an important barrier because religious, cultural, and political alliances may create strong webs of social relationships that make imitation virtually impossible. Thus, transnational firms must develop managers with experience in a variety of cultures, and those firms must provide those managers with training in cultural diversity. Those managers also need training and experience in how to manage transnational teams and alliances in decentralized, flattened organizations. The importance and use of transnational teams as well as their impact on staffing, training, and reward systems is increasing (Snell, Snow \& Hambrick, 1998). Experiential exercises may be needed to assist managers in those teams to develop skill in making decisions in the face of rapidly changing situations.

Third, for transnational firms, the non-substitutability of human resources becomes even more important. Superior human resources can be expected to protect a firm from substitutability because the resources that are likely to be substituted for human resources are themselves not inimitable. We used technology as an example and showed that technology is likely to be imitable, especially as competition becomes more global. As technology is imitated, human resources can be expected to recapture the advantage. Training and development of not only the managers of transnational firms but also of all employees of those firms is, then, clearly necessary to assure that superior human resources are available to the firms. Such training should have both broad conceptual aspects and very practical advice - don't use your left hand in Moslem countries; don't ask personal questions in the Middle East; and don't make direct eye contact in Japan, for instance.

Fourth, consistent with the model developed in Wright, McMahan, and McWilliams (1994), we demonstrated that, to achieve competitive advantage, 
managers must be able to identity individuals who possess higher quality human capital; to attract individuals who possess higher quality human capital; to retain individuals who possess higher quality human capital; and to encourage individuals to behave in a way that supports the organization's strategic goals. To focus on how the role of the manager changes as a firm globalizes, we examined the importance of international training, experience, and perspective for top managers in transnational firms (see also, Mallampally, 1997).

As Adler and Bartholomew (1992a) point out, many transnational firms are having difficulty implementing well-thought-out strategies because top management lacks international experience and an understanding of the worldwide business environment from a global perspective. Therefore, these managers are not able to develop transnational human resource systems that take advantage of the recruiting and utilization opportunities that arise from having access to multiple human resource pools. Further, they are not exploiting the potential advantage that would result from developing a company culture around the possible cultural synergies.

Finally, our analysis highlights the role of multiple labor pools in global competitiveness. The existence of multiple labor pools creates additional sources of potential sustainable competitive advantage for transnational firms. These include 1) the ability to draw from more than one labor pool, 2) the opportunity to exploit cultural synergies, and 3) the ability to overcome stickiness. Especially important to the first effect is the ability of superior human resources to adapt quickly and effectively to new technologies developed in facilities of the organization in different countries. Especially important to the second effect is the ability of top managers to develop truly transnational human resource systems that are characterized by a global "frame of mind," transnational representation across top management teams, and multicultural decision making and planning processes (Adler \& Bartholomew, 1992a).

\section{Conclusions and Research Implications}

Managers in transnational firms should recognize the critical importance of human resources rather than attempting to rely heavily upon capital and technology for success. They must truly be transnational, striving for global integration with local responsiveness (Rothwell, Prescott \& Taylor, 1999). Managers in transnational firms should recognize the value of having access to multiple human resource pools. These expanded pools provide greater opportunity to locate qualified personnel capable of helping the firms achieve their objectives in a global environment. Human resource professionals should help managers develop awareness of cultural diversity both through training and also through direct experience on international assignments. Human resource professionals should also develop training programs for all employees on cultural diversity so that they are able to better deal with diversity and change. Those individuals 
should get involved in organizations in countries in which they operate Chambers of Commerce, policy-formulating governmental bodies, powerful civic organizations, and the like. Performance assessments should be restructured to include evaluations of effectiveness in adapting to and performing within the country in which the manager operates.

Managers in transnational firms and human resource professionals should recognize that HRM strategies will have local variations depending upon the laws and customs of differing countries. The design and management of employee benefit and compensation programs, for instance, are highly likely to necessitate local variation as are programs dealing with safety and health. Employee privacy and rights issues are also likely to vary from one country to another. The impact of the shadow work force and the use of temporary help may become even more complicated as personnel are able to cross national boundaries and become more mobile. The importance of a careful process for dealing with inpatriates is clear (Harvey, Speier \& Novicevic, 1999; Harvey \& Buckley, 1997).

There has been a void in knowledge and practice where global corporate strategy and human resource management intersect. Hopefully, focusing on the model presented in this paper will enable both researchers and practitioners to fill that void (Adler \& Bartholomew, 1992b). Researchers might investigate, for instance, the specific impact of multiple human resource pools. Are the benefits derived from having simply more than one pool or are numerous pools required? Is involvement, as suggested by Lawler (1996), necessary in every country in which a firm operates or only in those in which it is compatible with local cultures? These and other specific research questions can readily be derived from the model. The role of technological learning that takes place in transnational human capital pools is largely supported only through case studies and merits stronger empirical research (Zahra, Ireland \& Hitt, 2000). The answers to such questions would go a long way towards improving the practice of human resource management in transnational organizations.

That research, however, will need to be different from that to which most management scholars are accustomed. Rouse and Daellenbach (1999) have shown very clearly that research methods dealing with the resource-based view will need to be crafted very carefully particularly when one is investigating the concept of sustainable competitive advantage. While much strategic management research relies on secondary sources of information from large sample, multi-industry, single time-period samples, those approaches are not applicable to studying sustainable competitive advantages. ${ }^{3}$ Because the sample is so critical, they propose a four-step selection process. Step One is to select a single industry. Step Two is to "cluster firms by strategic type or group within the industry selected" (Rouse \& Daellenbach, 1999, 489), and to validate the clustering. Step Three involves comparisons of performance indicators within these strategic groupings. Step Four then involves careful internal analysis of simi- 
larities and differences between high and low performers within each group. Research done using this framework will likely shed more light on the role of human resources in organizations.

This paper, then, sheds light on the importance of a firm's human resources for achieving competitive advantage in a global marketplace. It points to the fact that human resources are a potential source of sustainable competitive advantage, and one over which managers have influence. Further research and observation will refine and clarify the model presented here so that both the theory and practice of transnational human resource management will continue to develop and improve.

\section{References}

Adler, N. (1991). International dimensions of organizational behavior. Boston: PWS Kent.

Adler, N. \& Bartholomew, S. (1992a). Managing globally competent people. Academy of Management Executive. 6, 52-65.

Adler, N. \& Bartholomew, S. (1992b). Academic and professional communities of discourse: Generating knowledge on transnational human resource management. Journal of International Business Studies, 23, 551-569.

Adler, N. J. \& Ghadar, F. (1990). International strategy from the perspective of people and culture: The North American context. Research in Global Business Management, 1, 183-184.

Alchian, A. \& Demsetz, H. (1972). Production, information costs, and economic organization. American Economic Review, 62, 777-95.

Amit, R. \& Schoemaker, P. J. H. (1993). Strategic assets and organizational rent. Strategic Management Journal, 14, 33-46.

Barney, J. (1991). Firm resources and sustained competitive advantage. Journal of Management, 17, 99-120.

Bartlett, C. A. \& Ghoshal, S. (1998). Managing across borders. Boston: Harvard Business School Press.

Bass, B. M. \& Burger, P. C. (1979). Assessment of managers: An international comparison. New York: Free Press.

Becker, G. (1964). Human capital. New York: Columbia U. Press.

Besanko, D., Dranove, D. \& Shanley, M. (2000): Economics of strategy. (2nd ed.), New York: John Wiley. 
Black, J. S. \& Porter, L. W. (1991). Managerial behaviors and job performance: A successful manager in Los Angeles may not succeed in Hong Kong. Journal of International Business Studies, 22 (1), 99-113.

Boudreau, J. W. (1991). Utility analysis for decisions in human resource management. in M. D. Dunnette and L. M. Hough (Eds.), Handbook of industrial and organizational psychology. (2nd ed.), (Vol. 2, pp. 621-745), Palo Alto, CA: Consulting Psychologists Press.

Bresman, H., Birkinshaw, J. \& Nobel, R. (1999). Knowledge transfer in international acquisitions. Journal of International Business Studies, 30 (3), 439-462.

Doz, Y. \& Prahalad, C. K. (1988). Quality of management: An emerging source of global competitive advantage," In N. Hood and J. Vahine (Eds.), Strategies in global competition. London: Croom Helm.

Flamholtz, E. \& Lacey, J. (1981). Personnel management: Human capital theory and human resource accounting. Los Angeles: Institute of Industrial Relations, UCLA.

Flint, G. D (2000). What is the meaning of competitive advantage? Advances in Competitiveness Research. 8 (1), 121-129.

Goldstein, I. (1991). Training in organizations. In M. D. Dunnette and L. M. Hough (Eds.), Handbook of industrial and organizational psychology. (2nd ed.), (Vol. 2, pp. 507-619), Palo Alto, CA: Consulting Psychologists Press.

Grant, R. M. (1991). The resource-based theory of competitive advantage: Implications for strategy formulation. California Management Review. 33, 114-135.

Griffin, R. W., \& Pustay, M. W. (1996). International business: A managerial perspecIive. Reading, MA: Addison-Wesley Publishing Company.

Guion, R.M. (1991). Personnel assessment, selection and placement. In M. D. Dunnette and L. M. Hough (Eds.), Handbook of industrial and organizational psychology. (2nd ed.), (Vol. 2, pp. 327-397), Palo Alto, CA: Consulting Psychologists Press.

Hannon, J. M., Huang, I. \& Jaw, B. (1995). "International human resource strategy and its determinants: The case of subsidiaries in Taiwan. Journal of International Business Studies, 26, $531-554$.

Hansen, M. T. (1999). The search-transfer problem: The role of weak ties in sharing knowledge across organizational subunit. Administrative Science Quarterly, 44 (1), 82-111.

Harrigan, K. \& Dalmia, G. (1991), Knowledge workers: The last bastion of competitive advantage. Planning Review, Nov-Dec., 4-48. 
Harvey, M. G. \& Buckley, M. R. (1997). Managing inpatriates: Building a global core competency. Journal of World Business, 32, 35-52.

Harvey, M. G., Speier, C. \& Novicevic, M. M. (1999). The role of inpatriates in a globalization strategy and challenge associated with the inpatriation process. $\mathrm{Hu}$ man Resource Planning, 22, 38-50.

Hashimoto, M. (1981). Firm-specific human capital as a shared investment. American Economic Review, 71, 475-482.

Hitt, M. A., Tyler, B. B., Hardee, C. \& Park, D. (1995) Understanding strategic intent in the global marketplace. Academy of Management Executive 9, 12-19.

Hitt, M. A., Dacin, M. T., Levitas, E., Arregle, J. \& Borza, A. (2000). Partner selection in emerging and developed market contexts: Resource-based and organizational learning perspectives. Academy of Management Journal, in press.

Hunter, J. \& Hunter, R. (1984). Validity and utility of alternative predictors of job performance. Psychological Bulletin. 96, 72-98.

Jenson, A. R. (1980). Bias in mental testing. New York: Free Press.

Kanter, R. M. (1991). Transcending business boundaries: 12,000 world managers view change. Harvard Business Review, May-June, 151-164.

Kim, P. S. (1999). Globalization of human resource management: A cross-cultural perspective for the public sector. Public Personnel Management, 28, 227-243.

Lawler, E. E., III (1992). The ultimate advantage. San Francisco: Jossey-Bass Publishers.

Lawler, E. E., III (1996). From the ground up. San Francisco: Jossey-Bass Publishers.

Lee, Y. \& Larwood, L. (1983). The socialization of expatriate managers in multinational firms. Academy of Management Journal, 26, 657-65.

Madhok, A. \& Tallman, S. D. (1998). Resources, transactions and risks: Managing value through interfirm collaborative relationships. Organization Science, 9 , 326-339.

Mallampally, P. (1997). Transnational corporations and human resource development. Prospects, 27, 55-78.

Mansfield, E. (1984). R\&D and innovation: Some empirical findings. In Z. Griliches (Ed.), R\&D patents and productivity. Chicago: University of Chicago Press.

Mead, R. (1998). International management: Cross-cultural dimensions. (2nd ed.), Oxford: Blackwell Publishers Lid. 
Mendenhall, M. \& Oddou, G. (1985). The dimensions of expatriate acculturation. Academy of Management Review, 10, 39-47.

Miller, D. \& Shamsie, J. (1996). The resource-based view of the firm in two environments: The Hollywood film studios from 1936 to 1965. Academy of Management Journal, 39, 519-543.

Norton, R. (1993). Will a global slump hurt the U.S.? Fortune, February 20, 1993, 63-64.

Osborn, R. N. \& Hagedoorri, J. (1997). The institutionalization and evolutionary dynamics of interorganizational alliances and networks. Academy of Management Journal, 40, 261-278.

Pennings, J. M., Lee, K. \& van Witteloostuijn, A. (1998). Human capital, social capital, and firm dissolution. Academy of Management Journal. 41, 425-440.

Peteraf, M. A. (1993). The cornerstones of competitive advantage: A resource-based view. Strategic Management Journal, 14, 179-192.

Prahalad, C. K. \& Hamel, G. (1990). The core competence of the corporation. Harvard Business Review, 68, 79-91.

Ratiu, I. (1983). Thinking internationally: A comparison of how international executives learn. International Studies of Management and Organization, 13, 139-150.

Reed, R. \& DeFillippi, R. (1990). Causal ambiguity, barriers to imitation, and sustainable competitive advantage. Academy of Management Review, 15, 88-102.

Ricks, D. (1993). Blunders in international business. Cambridge, MA: Blackwell Business.

Rothwell, W. J., Prescott, R. K. \& Taylor, M. (1999). Transforming HR into a global powerhouse. HR Focus, March, 7-8.

Rouse, M. J. \& Daellenbach, U. S. (1999). Rethinking research methods for the resource-based perspective: Isolating sources of sustainable competitive advantage. Strategic Management Journal, 20, 487-494.

Schoenecker, T. S. \& Cooper, A. C. (1998). The role of firm resources and organizational attributes in determining entry timing: A cross-industry study. Strategic Management Journal, 19, 1127-1143.

Schuler, R. S., Dowling, P. \& De Cieri, H. (1993). An integrative framework of strategic international human resource management. Journal of Management, 19, 419-459. 
Si, S. X. \& Bruton, G. D. (1999). Knowledge transfer in international joint ventures in transitional economies: The China experience. Academy of Management Executive, 13 (1), 83-90.

Simonin, B. L. (1999). Transfer of marketing know-how in international strategic alliances: An empirical investigation of the role and antecedents of knowledge ambiguity. Journal of International Business Studies, 30 (3), 463-490.

Snell, S. A., Snow, C. C. \& Hambrick, D. C. (1998). Designing and supporting transnational teams: The human resource agenda. Human Resource Management. $\underline{37}, 147-158$.

Snow, C., \& Snell, S. (1992). Staffing as strategy. In N. Schmitt and W. Borman (Eds.), Personnel Selection. (Vol. 4), San Francisco: Jossey-Bass.

Steffy, B. \& Maurer, S. (1988). Conceptualizing and measuring the economic effectiveness of human resource activities. Academy of Management Review, 13, 271-286.

Storck, J. \& Hill, P. A. (2000). Knowledge diffusion through 'strategic communities.' Sloan Management Review, 41 (2), 63-74.

Szulanski, G. (1996). Exploring internal stickiness: Impediments to the transfer of best practice within the firm. Strategic Management Journal. 17, 27-43.

Trompenaars, F. (1993). Riding the waves of culture. London: Nicholas Brealey.

Tung, R. (1981). Selecting and training of personnel for overseas assignments. Columbia Journal of World Business, $16,68-78$.

Watson, W., Kumar, K. \& Michaelson, L. (1993). Cultural diversity's impact on interaction process and performance: Comparing homogeneous and diverse task groups. Academy of Management Journal, 36, 590-602.

Welch, D. (1994). "HRM implications of globalization. Journal of General Management. $19,52-66$.

Wernerfelt, B. (1984). A resource based view of the firm. Strategic Management Journal. $5,171-180$.

Wernerfelt, B. (1995). The resource based view of the firm: Ten years after. Strategic Management Journal, 16, 171-174.

Wright, P. M. \& Snell, S. A. (1991). Toward an integrative view of strategic human resource management. Human Resource Management Review, 1, 203-225. 
Wright, P. M., McMahan, G. \& McWilliams, A. (1994). Human resources and sustained competitive advantage: A resource-based perspective. International Journal of Human Resource Management, 5 (2), 301-26.

Zahra, S. A. Ireland, R. D. \& Hitt, M. A. (2000). International expansion by new venture firms: International diversity, mode of market entry, technological learning and performance. Academy of Management Journal, in press.

Zupan, M. A. (1991). Paradigms and cultures: Some economic reasons for their stickiness. American Journal of Economics and Sociology, 50 (1), 99-104.

\section{Endnotes}

' By competitive advantage, we mean that a firm or business unit has higher than average profits for firms in its market. While this is a commonly used definition (Besanko, Dranove \& Shanley, 2000, p. 389), the precise meaning of that and related terms is only now being clarified in the literature (see Flint, 2000).

${ }^{2}$ There are no generally accepted definitions of terms for organizations whose activities cut across national political boundaries. Definitions vary depending in part on the emphasis placed on the location of operations (all production in one country, a few countries, or widely dispersed), markets (all sales in one country, a few countries, or widely dispersed), or ownership (all owners citizens of only one country, usually the country of incorporation; owners citizens of a limited number of countries; owners spread widely over the whole world). However, legal arrangements (country in which incorporated), the dominance of cultural or national groups in organizational activities, and strategies (worldwide uniformity, worldwide presence but with regional/local differences, and so on) are also frequently part of definitions. Many of the general terms used (international, global, multidomestic, transnational, and multinational) have different meanings to different people, and some are used almost interchangeably. Therefore, it is extremely important that the reader uses the same set of definitions as do the authors. Adler's (1991) set of definitions is used here because they are widely recognized by management scholars and practitioners alike.

${ }^{3}$ While a thorough review of the Rouse and Daellenbach (1999) treatment is not presented here, they note that significantly different results are obtained for business segment-specific effects relative to industry effects and that the very definition of competitive advantage restricts relevant analysis to only selected firms (those with "best practices") in particular industries. Research using the resource-based view to study sustainable competitive advantages will, then, investigate the internal workings of carefully selected firms. 
Abagail McWilliams is Head of the Managerial Studies Department at the University of Illinois at Chicago. She received her bachelor's degree in business administration, and her master's and doctoral degrees in economics from The Ohio State University. Her research interests include strategic management, strategic human resource management, gender issues in labor mobility, and the link between firm performance and corporate social responsibility.

David D. Van Fleet is Professor of Management at Arizona State University West. He has 37 years of teaching experience, over 180 publications and presentations, and has consulted in the United States and abroad. He is a past President of the Southwest Academy of Management and the Southern Management Association. He served on the Board of Governors of the Academy of Management and is a Fellow of the Academy of Management and the Southern Management Association.

Patrick M. Wright is Professor of HR Studies and Chair of the HR Studies Department in the School of Industrial and Labor Relations, Cornell University. He holds a BA in psychology from Wheaton College, and an MBA and a Ph.D. in OB/HRM from Michigan State University. He teaches and conducts research in the area of Strategic Human Resource Management, particularly focusing on how firms use people as a source of competitive advantage. 